\title{
PLASMA SCIENCE AND TECHNOLOGY
}




\section{Also by Herman V. Boenig}

Unsaturated Polyesters: Structure and Properties

Polyolefins: Structure and Properties

Structure and Properties of Polymers 


\section{PLASMA SCIENCE AND TECHNOLOGY}

\section{Herman V. Boenig}

Cornell University Press

Ithaca and London 
Copyright (C) 1982 by Cornell University Press

All rights reserved. Except for brief quotations in a review, this book, or parts thereof, must not be reproduced in any form without permission in writing from the publisher. For information address Cornell University Press, 124 Roberts Place, Ithaca, New York 14850.

First published 1982 by Cornell University Press.

Published in the United Kingdom by Cornell University Press Ltd., Ely House, 37 Dover Street, London W1X 4HQ.

Printed in the United States of America

\section{Library of Congress Cataloging in Publication Data}

Boenig, Herman V.

Plasma science and technology.

Includes bibliographical references and index.

1. Plasma (Ionized gases) 2. Polymers and polymerization. I. Title.

QC718.B56 $530.4^{\prime} 4$

ISBN 0-8014-1356-7

$81-15200$

AACR2 